\title{
INTERNATIONAL HYDROGEOLOGICAL MAP OF EUROPE: SHEET D6 "ATHINA"
}

\author{
Nikas K. ${ }^{1}$, Antonakos A. ${ }^{2}$, Kallergis G. ${ }^{3}$ and Kounis G. ${ }^{1}$ \\ ${ }^{1}$ Institute of Geological and Mineral Exploration (IGME), Spirou Loui 1, Olympic Village Thrakomake- \\ dones,Greece, k_nikas2006@yahoo.gr \\ ${ }^{2}$ General Secretariat for Civil Protection, Evagelistrias 2, 10563 Athens, aantonako@yahoo.gr \\ ${ }^{3}$ Emeritus Professor, University of Patras, georgios.kallergis.1@ontelecoms.gr
}

\begin{abstract}
Hydrogeological maps adopting international standards and covering the whole Greek territory are lacking today in Greece. Sheet D6 - Athina of the International Hydrogeological Map of Europe, scale 1:1,5 million can serve, among many other uses, for such a map. Although relatively limited amount of hydrogeological information is conveyed in the map, because of its small scale, it can serve very well as a guide for information, teaching purposes, planning and scientific work. Besides, because it has fully adopted the standards set from a number of relevant organisations (IAH, IAHS, COHYM, CGMW, UNESCO etc) for the compilation of such kind maps, it can serve equally well as a model for the generation of larger scale Hydrogeological maps.
\end{abstract}

Key words: Europe, Hydrogeological Map, IAH, hydrolithological categories.

\section{Introduction}

A picture says more than a thousand words, but a map says more than a thousand pictures. Maps were already being used by medieval scientists even though such maps today may appear very naïve. A more scientific approach was only possible with the advent of land surveying and spheric trigonometry.

Geologists were among the first to develop techniques for mapping. Thanks to international scientific organisations, a high degree of standardisation with regard to presentation, inherent philosophy and legends with recommended symbols, ornaments and colours, had already been arrived at more than a century ago. On the basis of local, (large-scale) regional maps, national maps were developed and, with the appearance of atlases, the need for continental maps arose. Geological maps included in atlases are generally at an extremely small scale, often 1:5,000,000 or even 1: 10,000,000. It is evident that such a small scale map can only depict very general features such as the general location and disposition of aquifers and non-aquifers, together with a broad picture of the surface drainage. For more detailed information it is obvious that a map needs a larger scale, e.g., 1: 1,000,000.

\section{The International Hydrogeological Map of Europe}

In 1960, the International Association of Hydrogeologists (IAH- International Association of Hydrogeologists) initiated a project for the preparation of an International Hydrogeological Map of Europe (IHME), having realized that although a large number of hydrogeological maps at various scales existed in almost all European countries, none of them were the same in their scientific ap- 
proach, content, presentation, or use of cartographic symbols, making comparison practically impossible and even leading to erroneous conclusions. The fact that no obvious effort was being made to prepare maps in a uniform way lead to the suggestion that a small-scale map covering the whole of Europe should be prepared. However, even for a relatively small continent like Europe, such a map exceeds normal paper size. To remedy this situation, therefore, it was decided to divide the surface area into a composite of several maps.

The general purpose of the map was to provide a simplified representation of ground water in Europe as related to the geological situation. The main objective was to show the location, geographic extent, movement and constitution of the major groundwater bodies, classified according to the main types of aquifers.

Whereas large-scale maps are used for practical purposes and therefore need to contain as many details as possible, maps on a medium or small scale only give a general picture and are used primarily for information, teaching purposes, planning and scientific work.

In order to prepare an international map, agreement must be reached by the participating countries and international organisations regarding scale, an easily applicable legend and a meaningful scientific approach. Since the suggested map was the first international venture in the field of hydrogeological mapping, it was essential, from the very beginning, to secure the collaboration of a large number of scientists and to make full use of the experience of countries with a long tradition in mapping activities and hydrogeology. It is, therefore, not surprising that it took ten years to gather and evaluate such information and to establish suitable models for discussion by the scientists involved. Although the model which was finally adopted had been discussed in great detail, serious problems emerged during the preparation of the actual map, and these had to be solved at international level. The compilation of the sheets comprising the map is far from being a routine job and shows that hydrological mapping needs to be developed further. At the start of the actual work, it was understood that both the legend applied and the scientific approach had to be flexible so that, on the one hand, individual or unique events could be shown and, on the other, the necessary uniformity and clearness of the map could be maintained. The history of this map, therefore, reflects an attempt at perfection and an aim for uniformity, as well as the peculiarities of an international undertaking. These peculiarities stem from the different ways of identifying problems in different countries, from varying hydrogeological interpretations to different national regulations concerning the compilation and publication of data and information. These rather limiting factors and the varying amount of information available in each country would have led to an unjustified simplification of the map if the permitted or actual minimum of information available in certain countries had been taken as a standard. This difficulty was overcome by the flexible nature of the map which contains all information necessary for the understanding of the hydrogeological situation.

Historically, as it has already been said the Project was established in the sixties of the last century. Since then the project has passed the following stages of preparation:

1960 XXI International Geological Congress in Copenhagen: IAH Commission on Hydrogeological Maps (COHYM) was appointed to prepare a small-scale European Hydrogeological Map project (to serve as a model for small-scale hydrogeological maps in other parts of the world)

1962 Preprint (black \& white) of an International Legend for Hydrogeological Maps

1970 Coloured print of an International Legend for Hydrogeological Map Basis for

1974 General Legend for the International Hydrogeological Map of Europe 
1970 Print of the first sheet C5-Bern

1985 Print of 15 sheets, usually with explanatory notes

1986-1998 Project stagnated (due to changes in East and Southeast Europe).Only 4 sheets were prepared by BGR

1998 UNESCO and BGR started a new work program for the completion of the map project on the Iberian Peninsular and in SE - Europe

1999 XXIX IAH Congress in Bratislava: Regional Editorial Meeting for the implementation of Sheet D5-Budapest (12 countries involved)

4/2000 Editorial Meeting in Madrid for the implementation of the Sheets A5-La Coruña and C6-Lisboa)

9/2000 Regional Editorial Meeting in Bucharest for the implementation of Sheet E5-BucureSti (5 countries Involved)

11/2002 Regional Editorial Meeting in Athens for the implementation of Sheet D6-Athens (9 countries Involved)

More specifically, the compilation of sheet D6 -Athina initiated in the early eighties. The Greek Institute of Geological and Mineral Exploration (IGME) provided the first two National editors (G. Kallergis and G. Kounis). As it has already been said, political and economic problems in South-East Europe but also organisational and financial difficulties in the supporting agencies Unesco and BGR, resulted in stagnation in working on the map for more than 20 years. In 2002 due to a new initiative of Unesco and the BGR the program reactivated. A regional meeting was held at that year in IGME Athens with all participating countries and decisions were taken towards the finalisation of the map. IGME provided also the Scientific Sheet Editor/Coordinator (K. Nikas) taking into account that the old editors had already been retired. K Nikas was assisted in his national editorial work by Mr. A. Antonakos who worked at that time for IGME.

\subsection{Choice of Scale for the International Hydrogeological Map of Europe}

When choosing a scale there must always be a compromise between the size of the paper, the number of sheets forming the composite, and the amount of information to be included. The European geologists agreed to a scale of $1: 1,500,000$ which allows sufficient detail but which is still viable economically and is also easy to use. The individual map sheets are organized in a pattern with horizontal (numbers) and vertical (letters) rows. Each sheet has a key (say B5) and is named after an important city (e.g. Paris). Since a map on flat paper never fully concurs with reality (curved earth surface) a projection has been chosen which, for the European degrees of latitude, minimises the deviations from reality. This projection as well as the geographic base map were provided by the Commission for the Geological Map of the World (CGMW), affiliated to the International Council of Scientific Unions (ICSU) and the International Union of Geological Sciences (IUGS).

In view of the success of the International Geological Map of Europe the same scale and division of sheets has been applied for the metallurgenic map and the Quarterny map of Europe.

It was logical to issue a hydrogeological map at the same scale, with the same projection and topographic base. The advantages are obvious: low cost, easy comparability, similar scientific approach, similar systematic. 
International Hydrogeological Map of Europe 1:1500 000

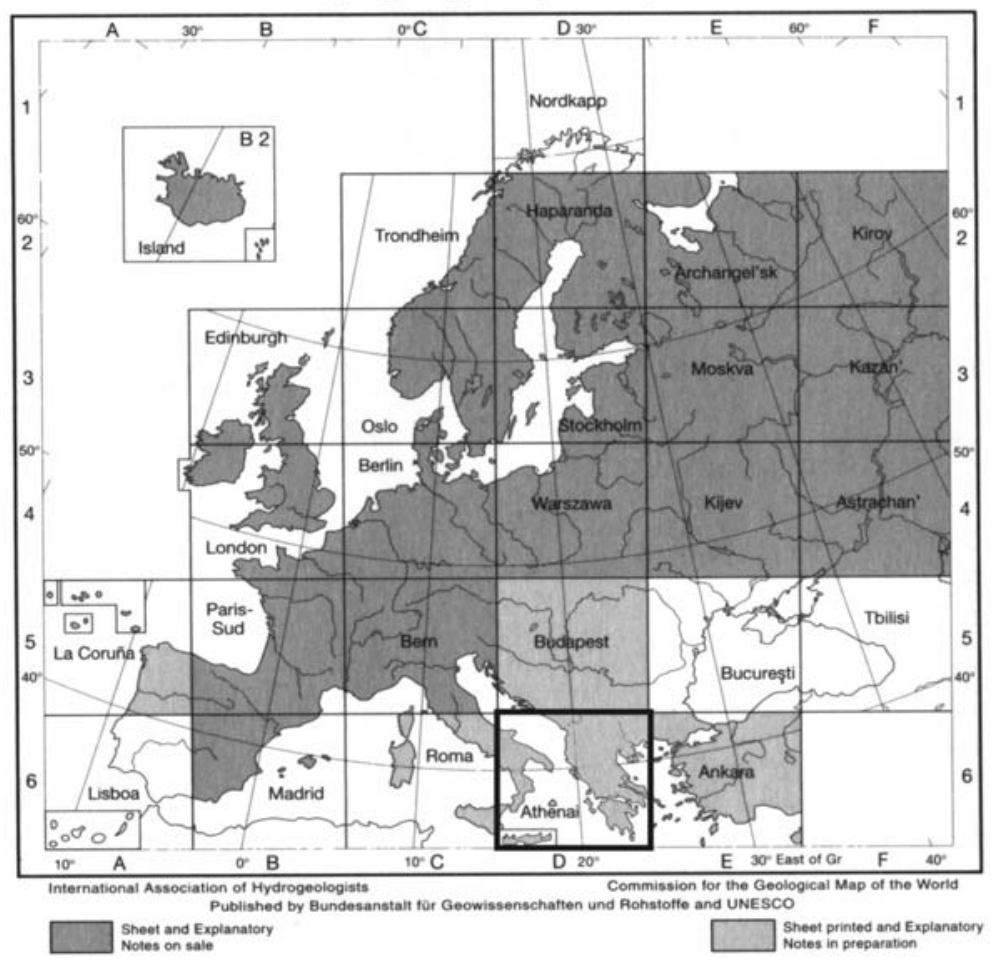

Fig. 1: State of preparation of IHME sheets.

\subsection{General characteristics}

The map has been drawn up along the same lines as the International Geological Map of Europe. While the latter consists of 49 sheets, the International Hydrogeological Map of Europe will no doubt be composed of less than 35 sheets, as certain regions outside Europe, in particular North Africa, will not be included. However, available space on the map will be used to portray Iceland, parts of Ireland and the island of Crete. Each sheet measures approximately 92 x $69 \mathrm{~cm}$ and contains not only a section of the map but also the legend in English, German and another language, either French, Russian or Spanish, depending on the country depicted. Cross sections, details of groundwater yield and quantity, together with a bibliography are also shown.

In order to make the map comparable with other international maps as well as to save costs, it seemed advisable to compile the map according to the scale used in other related maps. As the International Geological Map of Europe was prepared at a scale of 1: 1,500,000, the same scale was chosen for the Hydrogeological Map of Europe in view of the close connection between the geological structure and the hydrogeological features.

By using six colors (blue, green, red, brown, violet and orange - sometimes in different tones) as well as black and grey for point symbols, superimposures and lines, very detailed information concerning the aquifers, ground water, springs, surface water, artificial works and geological features has been included on the map. The following is a brief summary of the actual contents: 
a) Sky blue has been used for ground water in porous rocks; the depth of the blue indicates whether the aquifer is extensive and highly productive or whether it is local or incoherent. Superimposures refer to the type of rock and are applied in accordance with the stratigraphical symbols in the legend of the International Geological Map of Europe.

b) Green refers to ground water in jointed massive rocks; the depth of the colour indicates either extensive and highly productive aquifers, often found only at great depth, or local or incoherent aquifers into which streams flow.

c) Brown indicates regions generally without or only with local ground water; the depth of the colour indicates either that the aquifers are shallow or very deep but unproductive.

For a), b) and c) superimposures refer to the property and/or composition of the rock.

d) Violet lines may indicate, in special cases, the contour lines of the groundwater table, groundwater divides or boundaries of certain types of ground water.

e) Orange symbols refer to the quality of the ground water, and its temperature.

f) Royal blue symbols indicate springs giving the amount of discharge and the continuity of production.

g) Prussian blue indicates surface water.

h) Red symbols illustrate artificial works, such as wells, water-works, dams, canals and pipelines.

i) Black or green lines represent geological features, such as faults, overthrusts and border of certain formations.

k) The base map consists of grey lines.

A particular problem related to coloured maps should be raised here. Although the same printer was used for each map sheet, there are, nonetheless, slight differences in the colours between the different sheets as each series of map sheets was printed at varying intervals of time. When looking at one single sheet, the map and legend are homogenous. However, if two sheets, of a different series, are placed side by side slight differences become visible. Hence, at present, the composition of all the map sheets on a wall is not fully satisfactory. Modern technology can surely overcome this problem when and if all the map sheets are re-printed at some time in the future.

\subsection{Legend for the International Hydrogeological Map of Europe}

The IAHS (International Association of Hydrological Sciences) began studying the idea of a universally-applicable legend in 1954 and established a Standing Committee on Hydrogeological Maps in 1960 to study methods of presenting hydrological data on both small-scale and large-scale maps, and to make recommendations on the standardisation of symbols. The IAH also undertook the preparation of a legend from 1959 onwards and formed, for this purpose, a Working Group on Hydrogeological Maps. The legend was issued by IAHS and by UNESCO in 1963 with a view to having it tested by map-makers and hydrogeologists in different countries, under different hydrogeological conditions and at different scales. The experience gained from issuing this draft served for the establishment of a legend which was published by UNESCO and IAHS in 1970 in four of the working languages of UNESCO (Struckmeier \& Margat 1995).

Although not directly linked to the Hydrogeological Map of Europe but rather as a result of other 


\begin{tabular}{|c|l|}
\hline Ornament: & $\begin{array}{l}\text { a pattern of marks, lines or other symbol denoting the occurrence of a particular } \\
\text { factor over an area of ground as represented upon the map; e.g. a stipple to repre- } \\
\text { sent sandy strata. }\end{array}$ \\
\hline Symbol: & $\begin{array}{l}\text { a single graphical representation to denote the presence of a particular factor at a } \\
\text { point location on the map; e.g. a small circle to show the location of a spring. }\end{array}$ \\
\hline Line: & $\begin{array}{l}\text { a solid or broken line may be used either to delimit an area such as an aquifer out- } \\
\text { crop, or to join points of equal altitude (contour), equal thickness (isopachyte), or } \\
\text { similar parameters. }\end{array}$ \\
\hline Sign: & $\begin{array}{l}\text { a sign may consist of a line, a symbol, or an ornament, or a combination or any or } \\
\text { all of these. Colour: a colour refers to an even "wash" of constant tone. It may be used } \\
\text { for lines, symbols or ornaments as well as for emphasising areas of importance. }\end{array}$ \\
\hline Tone: & $\begin{array}{l}\text { screens may be used in order to reduce the density of a colour. The value of the } \\
\text { tone is usually expressed as a percentage of the original or full (100\%) colour. }\end{array}$ \\
\hline
\end{tabular}

B Groundwater and rocks

1. Intergranular aquifers

\begin{tabular}{|c|c|c|}
\hline blue & 1.1 & Extensive and highly productive aquifers \\
\hline $\begin{array}{c}\text { screened } \\
\text { blue }\end{array}$ & 1.2 & $\begin{array}{l}\text { Local or discontinuous productive aquifers } \\
\text { or extensive but only moderately productive } \\
\text { aquifers }\end{array}$ \\
\hline
\end{tabular}

2. Fissured aquifers, including karst aquifers

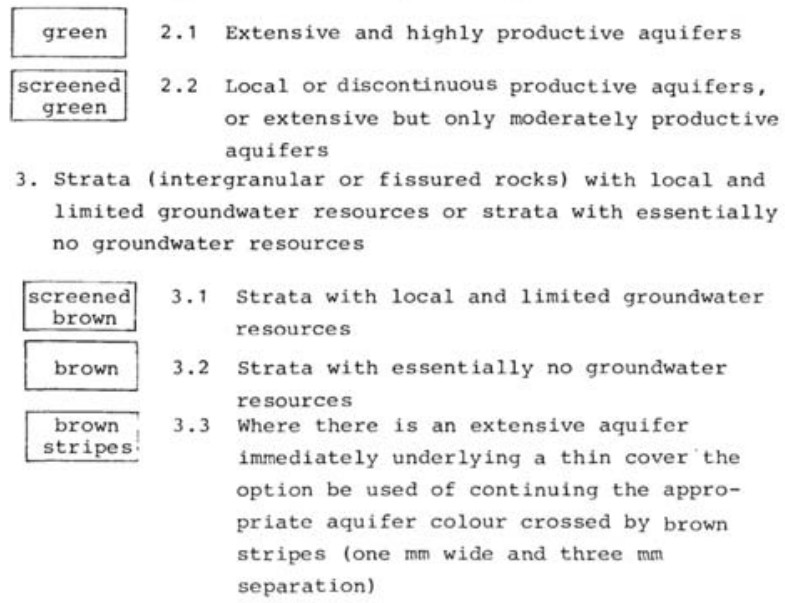

Fig. 2: Aquifer type proposed ornament by the standard legend of Hydrogeological Maps.

regional mapping projects, the 1970 issue of the standard legend was refined scientifically and regional supplements were also issued.

Certain terms are used rather loosely in both hydrogeology and cartogaphy, and it is easy for misunderstandings to arise. A short list of definitions is included here which refer to the usage for hydrogeological maps.

Some of the basic ornaments used in the standard legend for aquifer types, Lithology and groundwater features are shown in figures 3 to 4 . 


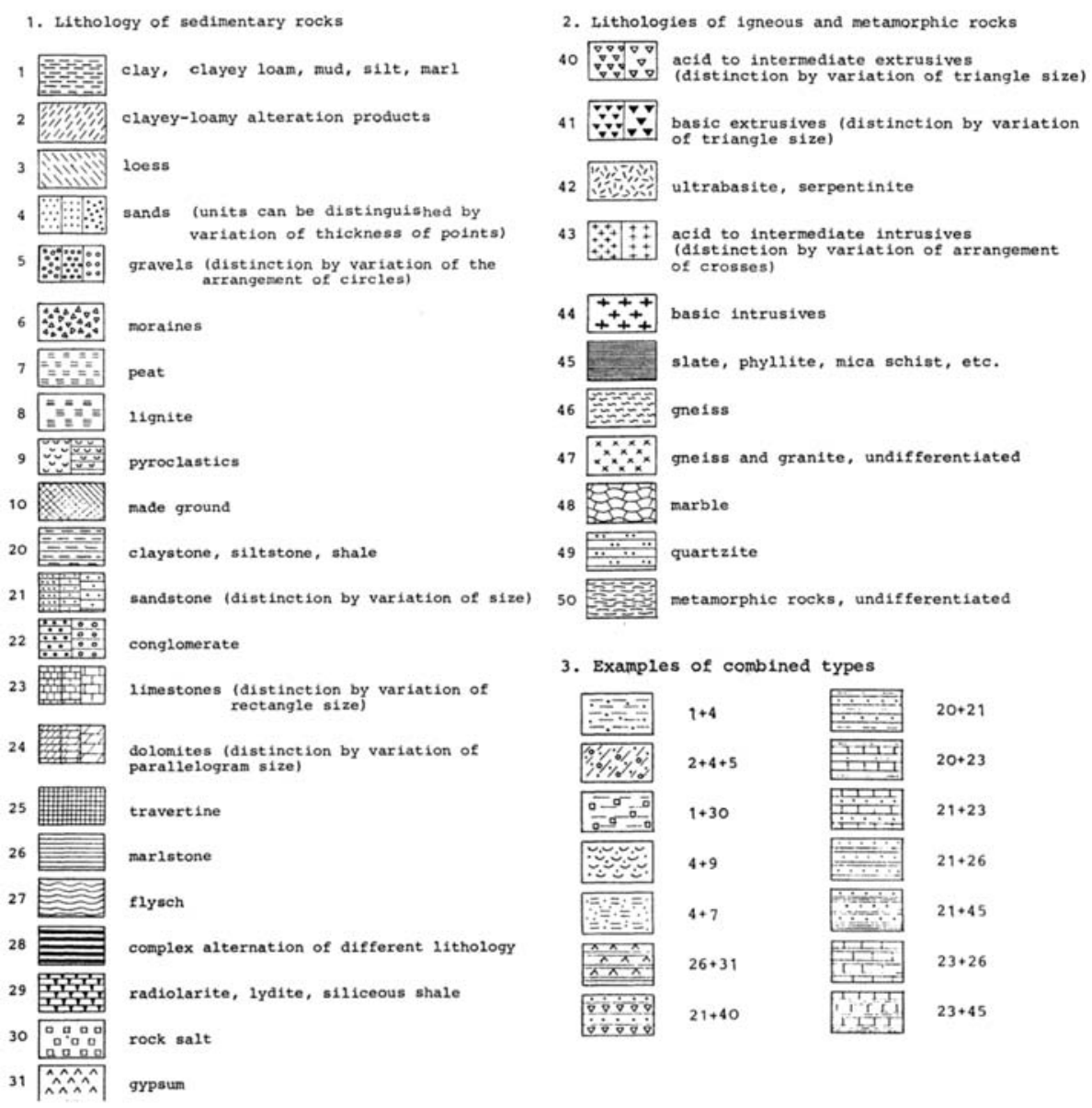

Fig. 3: Lithology proposed ornament by the standard legend of Hydrogeological Maps.

\section{Description of sheet D6 "Athina"}

Sheet D6 "Athina" includes the whole of Albania and FYROM and the largest part of Greece (Part of Thrace and eastern Greek islands of the Aegean Sea are included in the adjacent sheet of E6 Ankara). As a total, nine countries of the SE part of Europe contribute to the D6 sheet. The geographical distribution of these countries is shown in Figure 5 whereas in table 2 and Figure 6 the area and percentage of each country is shown.

As it can be seen from the table Greece occupies the larger part of the sheet namely $47 \%$ while Italy occupies 20\%, Albania, F.Y.R.O.M and Bulgaria almost $10 \%$ each and the rest $4.6 \%$ is occupied by other countries.

\section{The Greek part of sheet D6 "Athina"}

The preparation of the Greek part of sheet D6 was done by the use of Geographical Information Systems and incorporates the digitization of 75 aquifer types grouped in six categories. Polygon 


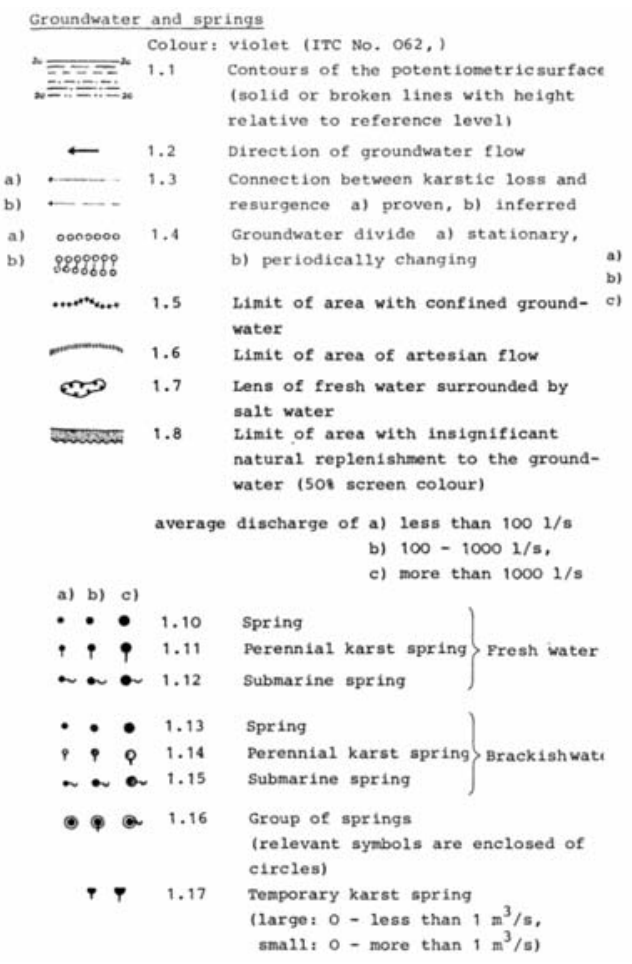

Fig. 4: Groundwater and surface water features proposed ornament by the standard legend of Hydrogeological Maps.

Table 2. Area distribution of countries participating in IHME sheet D6 “Athina”.

\begin{tabular}{|l|c|c|}
\hline COUNTRY & Area & Area (\%) \\
\hline GREECE & $117,576.1$ & 47.01 \\
\hline ITALY & $45,700.7$ & 18.27 \\
\hline ALBANIA & $28,624.4$ & 11.44 \\
\hline F.Y.R.O.M & $25,348.2$ & 10.13 \\
\hline BULGARIA & $21,305.0$ & 8.52 \\
\hline SERBIA & $6,496.1$ & 2.60 \\
\hline MONTENEGRO & $4,636.1$ & 1.85 \\
\hline CROATIA & 277.0 & 0.11 \\
\hline BOSNIA HERCEGOVINA & 154.9 & 0.06 \\
\hline SUM & $250,118.4$ & 100.00 \\
\hline
\end{tabular}

boundaries were adopted by the 1:1,500,000 geological map of Europe sheet D6, while the hydrogeological classification was done according to existing hydrogeological data and the judgment of the editors.

A huge number of hydrological and hydrogeological features were also digitized counting 572 karstic springs grouped in eight categories (Scagias 1978, 1986, Kourmoulis 1979, 1984, Kallergis and 


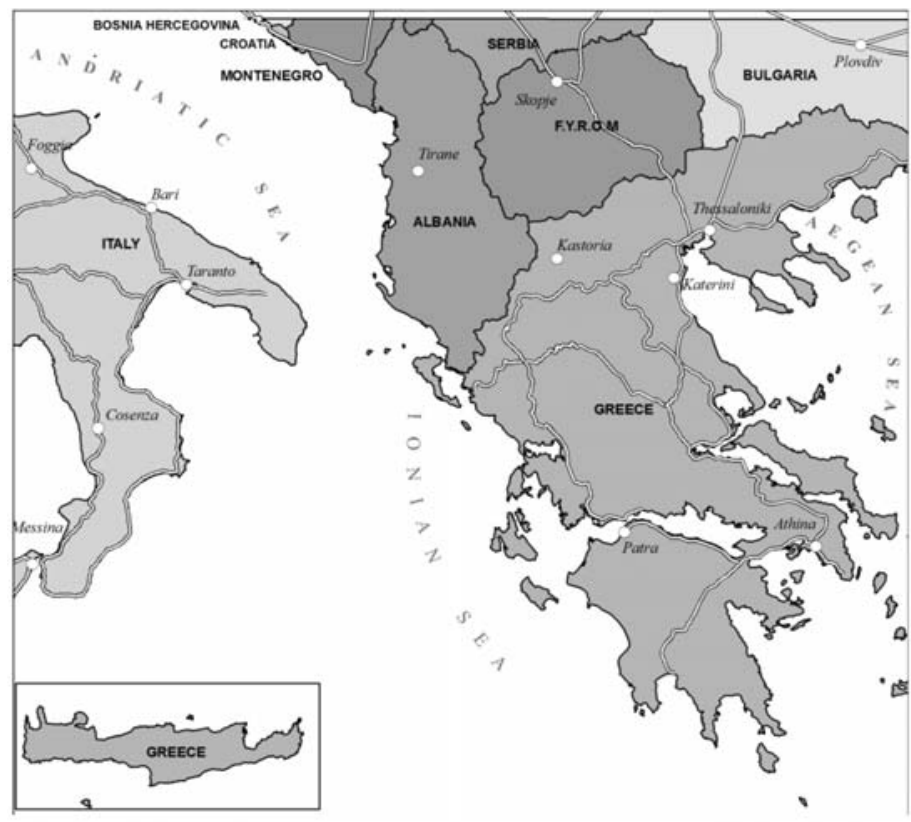

Fig. 5: Geographical distribution of countries participating in IHME sheet D6 "Athina".

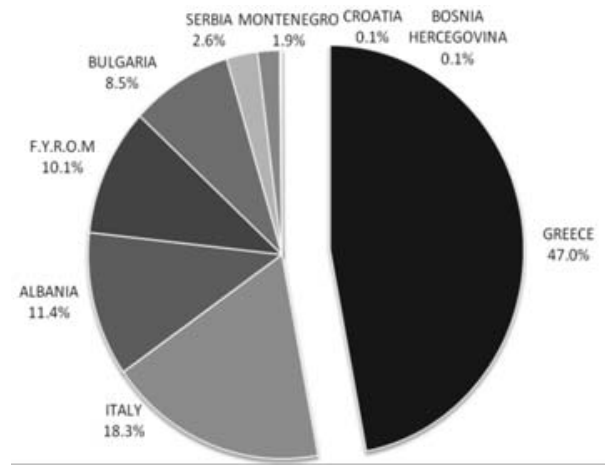

Fig. 6: Pie diagram of area distribution of countries participating in IHME sheet D6 "Athina”.

Scagias, 1980, Knithakis, 1983, Kakavas, 1984, Stamos and Manakos, 1986, Vergis, 1987) 298 mineral springs grouped in three categories (Orfanos et.al. 1995), 23 dams and 5 water tanks and their capacities (Hellenic Ministry of Rural Development and Food 2006), 22 major and 49 minor river basin boundaries, 4,339 $\mathrm{Km}^{2}$ of sea water intrusion zones and $3,030 \mathrm{Km}^{2}$ of artesian flow zones. Because this map has fully adopted the standards set from a number of relevant organisations (IAH, IAHS, COHYM, CGMW, UNESCO etc.) for the compilation of such kind of maps, can serve very well as a hydrogeological map of Greece, scale 1:1,5 million (Greek part of the map) as well as a model for the generation of larger scale Hydrogeological maps.

As it is understood the map due to its small scale includes many details presented by the use of colors and patterns that cannot be represented satisfactory here. Therefore the authors of this paper concluded that is better for the understanding of the readers the actual map to be shown as a poster 
during the time of the Congress. The actual map can be obtained from the IGME - Athens library (in due time also purchased from the UNESCO, http://publishing.unesco.org/maps.aspx) and in digital format (without legend) from the BGR web site at: http://www.bgr.de/app/fishy/ihme1500/

\section{Acknowledgments}

The writers would like to thank the BGR general editorial group and especially Mr.P.WINTER and Mr. H. STRUB, as well as the National editors- From Albania Mr. R. EFTIMI, Mr. Xh. SHEGUNAKU and Mr. I.TAFILAJ, from Bulgaria Mr. V. SPASSOV, from Bosnia and Herzegovina Mr. N. MIOSIC from Croatia Mr. T. MARKOVIC and Mr. Mr. SLISKOVIC, from Italy Mr. V. COTECCHIA, Mr. M. MANFREDINI, Mr. L. MARTARELLI and Mrs. A.R. SCALISE and from Serbia and Montenegro Mr.B. MIJATOVIC for contributing in the preparation of the D6 "Athina"map end for their excellent cooperation.

\section{References}

ANON. (1970): International Legend for Hydrogeological Maps - UNESCO/IAHS/IAH/Institute of Geological Sciences, 101 pp.; London.

Hellenic Ministry of Rural Development and Food, 2006. Dams and water tanks of the Ministry of Rural Development and Food. 104 pp. Athens (In Greek).

Kakavas, N., 1984. Inventory of karstic springs of Greece. VI. East Central Greece (Fthiotis Province). Abstract in English. IGME Athens.

Kallergis, G., Scagias, S. 1980. Inventory of karstic springs of Greece. III. Thessaly. Abstract in English. IGME Athens.

Knithakis, M., 1983. Inventory of karstic springs of Greece. IV. Hydrological basin of Strimonas R. IGME Athens.

Kourmoulis, N., 1987. Inventory of karstic springs of Greece. Eastern Central Greece (Prefectures of Phocida and Phtiotida). IGME Athens.

Kourmoulis, N., 1979. Inventory of karstic springs of Greece. II. Crete. Abstract in English. IGME Athens.

Kourmoulis, N., 1984. Inventory of karsic springs of Greece. V. Western Central Greece Abstract in English. IGME Athens.

Liakouris, D., 1995. Geology and dams of Public Power Corporation. Public Power Corporation S.A., 349 pp. Athens (In Greek).

Orfanos G., Sfetsos K., and Gioni G., 1995. Thermal-Mineral Springs Map of Greece scale 1:500.000. IGME Athens.

Scagias, S. 1978. Inventory of karstic springs of Greece. Inventory of karstic springs of Greece. I. Peloponnesus-Zakynthos-Kefallinia. IGME Athens.

Scagias, S. 1986. Inventory of karstic springs of Greece. VIII. Water District of Eastern Central Greece. (Euboea Province). IGME Athens.

Stamos, A., Manakos, A. 1986. Inventory of karstic springs of Greece. IX Water District of Western Macedonia. Abstract in English. IGME Athens.

Struckmeier, W., Margat, J. (Ed.) 1995: Hydrogeological Maps: a Guide and a Standard Legend. Int. Contibution to Hydrogeol., Vol. 17; Hannover.

Vergis, S., 1987. Inventory of karstic springs of Greece. Water District of Thrace. IGME Athens. 